Procedings of the New Zealand Grassland Association 53: 25-31 (1991)

\title{
Towards sustainable controls of pasture pests: Progress on control of Argentine stem weevil (Listronotus bonariensis (Kuschel))
}

\author{
R.A. PRESTIDGE, G.M. BARKER and R.P. POTTINGER \\ MAF Technology, Ruakura Agricultural Centre, Private Bag, Hamilton
}

\begin{abstract}
Pastures in the northern North Island contain a complex of nationally distributed insects and insects associated with warmer climatic conditions. Argentine stem weevil (Listronotus bonariensis (Kuschel)) is the most important insect pest in New Zealand. Progress toward the development of sustainable control of Argentine stem weevil is basedon a thorough understanding of the population ecology of the pest. The population size of Argentine stem weevil depends on the number of Acremonium lolii-freeryegrass tillersin thesward. Identification of $A$. lolii-free ryegrasses that are tolerant/resistant to Argentine stem weevil may improve ryegrass production and persistence without endangering animal health. The release of a South American parasite and the utilisation of naturally occurring pathogenic fungi together with tolerant/resistant ryegrasses has the potential to provide long term sustainable control of Argentine stem weevil in $\mathrm{p}$ a s t u r e s.
\end{abstract}

Keywords endophyte, plantresistance,pathogens, biological control

\section{Introduction}

Pastures and soils in the northern North Island contain a complex of pest species. Nationally distributed insects like Argentine stem weevil (Listronotus bonariensis (Kuschel)) and grass grub (Costelytra zealandica (White)) and pests associated with warmer climatic conditions like black beetle (Heteronychus arator F.), black field cricket (Teleogryllus commodus (Walker)), soldier fly (Inopus rubriceps (Macquart)) and white fringed weevil (Graphognathus leucoloma (Bohema)) occur together usually in free-draining soils. Mostly, these pests occur at densities below recognised economic thresholds and cause insidious damage, often reducing plant persistence and promoting changes in botanical composition. The effects are oftenexacerbated by warmer than average summer temperatures and high stocking rates which impose further stresses on pasture plants. Such damage is often attributed to drought, early senescence, disease, inadequate grazing management and soil factors which limit plant growth. For these reasons most farmers do not have a strategy for pasture pest control, and many become aware of pests only after visible damage has occurred.

The aim of pasture pest control has been to develop long term sustainable controls of key pests based on a sound understanding of their population ecology. Such controls are required for pests such as Argentine stem weevil, clover and grass nematodes, grass grub and white fringed weevil which are difficult or costly to control with pesticides.

This paper reports on progress towards sustainable management of Argentine stem weevil, focusing on the development of tolerant/resistant perennial ryegrasses (Lolium perenne L.) and biological controls.

\section{Current pest status of Argentine stem weevil}

Argentine stem weevil, a native of South America, was first recorded in New Zealand in 1927 (Marshall 1937). It infests most improved pastures in New Zealand and causes an estimated annual loss in animal productivity of up to \$251 million (Prestidge et al. 1991). Usually two, but occasionally three generations occur. In northern North Island perennial ryegrass pastures the spring generation is usually small and causes little pasture damage. The summer generation is larger and most damageusuallyoccurs from February to April. Insummer dry, east coast districts the spring generation may be large and cause significant pasture damage. Adults feed on leaves but generally this damage is not important unless spring/summer-sown crops and grass seedlings are checked by drought. Larvae tunnel inside grass tillers and mine the crown of the plant. Each larva may require 3-8 tillers during its development. Pastures less than 3 years old are at most risk, primarily because young grasses are less tolerant to insect predation than established grasses. 


\section{Endophyte-conferred plant resistance}

Before 1982, contradictory evidence on the relative susceptibility of perennialryegrass cultivars to Argentine stem weevil came from studies within and between different regions and under different nutritional and environmental conditions (see references in Prestidge et 01. 1982). The reason for the apparent contradictions becarneclearwiththeobservationthatryegrassesinfected with an endophytic fungus were resistant to Argentine stem weevil (Prestidge et al. 1982). The endophyte involved is Acremonium lolii Latch, Christensen \& Samuels (Latch et al. 1984, 1987).

Reports of endophyteassociated resistance to other insects quickly followed the discovery of endophyteconferred resistance to Argentine stem weevil (Funk et al. 1983; Ahmad et al. 1985; Hardy et al. 1985; Johnson et al. 1985; Latch et al. 1985; Kirfman et al. 1986; Clay 1990; Wilson ef al. 1991) (Table 1). In N ew Zealand, pest resistance in grasses associated with endophyte infection has been shown in 4 different pasturefeeding insect species (Table 1). Theknowneffects of endophyteconferred resistance are confined to the stages of these pests feeding above ground.

Undercontrolled conditions, Argentine stem weevil adult feeding and oviposition, and larval survival, are significantly less on A.lolii-infected ryegrass (Table 2) (Barker et al. 1984a, 1984b). Three classes of mycotoxin have been isolated from $A$. lolii-infected perennial ryegrass: the pyrrolopyrazine alkaloid, peramine; the indole alkaloids, lolitrem A-D; and the ergopeptine alkaloids, ergovaline and ergovalinine. Peramine and lolitrem $B$ are produced in vitro and are clearly fungalproduced compounds. Ergovaline has been detected only in Acremonium-infected grasses (Rowan \& Shaw 1987). Studies incorporating known concentrations of alkaloids produced by the endophyte into artificial diets have been pivotal in understanding the interactions between the endophyte and Argentine stem weevil. In concentrations commonly present in A. Zolii-infected ryegrasses, peramine deters larval and adult feeding, but is not toxic to larvae (Rowan \& Gaynor 1986; Dymock et al. 1989). Lolitrem B (and related indole compounds) reduces larval growth and increases larval mortality but is not toxic or deterrent to the adult stage (Prestidge \& Gallagher 1988; Gallagher \& Prestidge 1990). Ergotamine, one of the ergot alkaloids present in A. loliiinfected ryegrasses (Rowan \& Shaw 1987), reduces adult feeding but has no effect on larval growth or mortality (Dymock et al. 1989; Popay et al. 1990). Chemical analyses conducted on $A$. lofii-infectedryegrass and seed (Towers, N.R., pers. comm.) indicate that a number of other chemical compounds are present in $A$. Iolii-infected ryegrass, the biological activity of which we know little

Endophyte-conferred resistance to Argentine stem weevil has major consequences for ryegrass production and persistence (Prestidge $\boldsymbol{e t} \boldsymbol{a l}$. 1984; Barker $\boldsymbol{e t}$ al. 1986; Barker \& Baars 1989). In many areas of N ew Zealand Argentine stem weevil eliminates endophyte-

Table 1 Insect resistance in A. bolii , infected perennial ryegrass (*species present in New Zealand).

\begin{tabular}{lll}
\hline \multicolumn{1}{c}{ Common name } & \multicolumn{1}{c}{ Scientific name } & Reference \\
\hline Argentlne stem weevll & Listronotus bonariensis & Prestidge et al. 1982 \\
Sod webworm & Crambus spp. & Funk et al. 1983 \\
Bluegrass billbug & Sphenophorus parvulus & Ahmad et al. 1986 \\
Fall armyworm & Spodoptera frugiperda & Clay et al. 1985 \\
Pasture mealybug & Balanococcus poas & Pearson 1989 \\
Black beetle & Heteronychus arator & Ball and Prestidge 1992 \\
House crickets & Acheta domesticus & Ahmad et al. 1985 \\
Hairy chinch bug & Blissus leucopterus hirtus & Mathlas et a/. 1990 \\
Russian wheat aphid & Diuraphis noxia & Wilson et al. 1991 \\
Cutworm - & Graphania mutans & Dymock et al. 1989 \\
Common armyworm & Mythimna convecta & Frost et a/. 1990 \\
\hline
\end{tabular}

Table 2 Weevil feeding and oviposition response on Al\&i-infected $(+)$ and A.lolii-free $(-)$ ryegrasses in choice end no-choice tests. (Modified from Barker et al.1984a, 1984b).

\begin{tabular}{|c|c|c|c|c|c|c|c|c|}
\hline \multirow[b]{2}{*}{ Cultivar } & \multicolumn{4}{|c|}{ Feeding scars per weevil at 96 hours } & \multicolumn{4}{|c|}{ Number of eggs deposited per female weevil at 96 hours } \\
\hline & \multicolumn{2}{|c|}{ Choice } & No choice & & \multicolumn{2}{|c|}{ Choice } & \multicolumn{2}{|c|}{ No choice } \\
\hline Ellett & 1.3 & 8.2 & 0.9 & 4.2 & 0.7 & 2.9 & 0.7 & 2.1 \\
\hline Nui & 0.9 & 7.8 & 4.7 & 7.9 & 0.9 & 4.6 & 0.4 & 2.4 \\
\hline SED & \multicolumn{2}{|c|}{1.9} & \multicolumn{2}{|c|}{1.5} & \multicolumn{2}{|c|}{0.9} & \multicolumn{2}{|c|}{0.9} \\
\hline
\end{tabular}


free plants within 3-5 years of sowing. Hence the relative proportion of ryegrasses infected with A. lolii increases. Consequently, when low-endophyte seedlines of ryegrass are sown, the ryegrass content of the sward may decline to low levels, necessitating further pasture improvement (Figure 1).

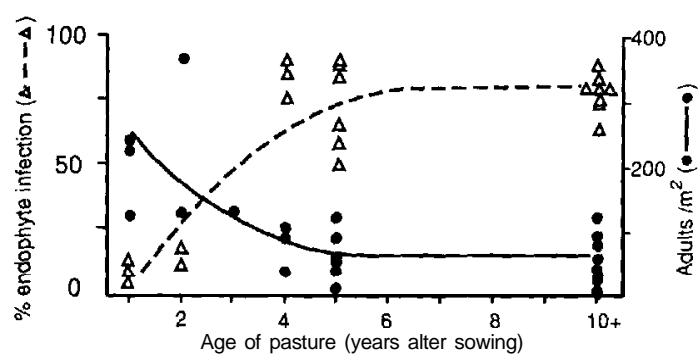

Figure 1 The percentage of A. lolii-infected perennial ryegrass and density of Argentine stem weevil in pastures of different ages in $M$ arch/A pril 1984. (Data from Prestidge etal. 1985, excluding pastures sown with high-endophyte ( $>80 \%$ ) seedlines of ryegrass).

Although farmers have been using $A$. Iolii-infected ryegrass seedlines to improve pasture production and persistence, it has been at a cost to grazing animals. Sheep, cattle, horses and deer grazing A. Iolii-infected ryegrass-dominan $t$ pastures in summer and autumn may develop ryegrass staggers, a temporary neuromuscular disease (Fletcher \& Harvey 1981; Mortimer 1983). Reducedw eightgainsinanimal shaveal sobeenreported (Fletcher 1986; Peterson et al. 1984). Rams (Petersonet al. 1978) and bulls (Peterson et al. 1984) grazing A. loliiinfected perennial ryegrass have reduced plasma testosterone levels, indicating possible adverse effects on reproductive performance. Fletcher \& B arrell(1984) reported reduced serum prolactin levels in ewe hoggets fed endophyte-infected perennial ryegrass which implicates the endophyte in reduced milk production. These studies and others (e.g. Vamey et al. 1989; Prestidge 1991) have highlighted important management and economic costs to animal production from the use of A. lolii-infected ryegrass pastures. Hence the dilemma faced by farmers of pasture damage by Argentine stem weevil or ryegrass staggers (and associated costs) continues.

Selection of A. Iolii strains which do not produce ryegrass staggers but with insect resistant properties is well advanced in New Zealand (Latch 1989, 1991; Prestidge 1991). The minimum quantity of endophyte mycelium (Prestidge et al. 1985) and peramine levels (Dymock et al. 1989; Popay et al. 1990) required to maintain Argentine stem weevil resistance in perennial ryegrass have been defined and selections of nil and lowlolitrem B strains have been achieved which maintain adequate peramine levels for insect resistance.

\section{Studies on population dynamics}

Studies in the northern North Island have shown that the size anddynamics of Argentine stem weevil populations are related to the number of $A$. Iolii-free tillers (Barker et al. 1986, 1989). In pastures where all perennial ryegrass plants are infected by $A$. lolii, as inoldpastures, population size is theoretically nil (Figure 2). In reality this is unlikely because of the presence of volunteer weed grasses. In pasture resown with endophyte-free ryegrasses, the weevils respond with increased reproductive effort, resulting in high larvalnumbers and high tiller mortality. As the endophytefree ryegrasses are eliminated from the pasture by selective weevil feeding, weevil populations decline to a stable low level.

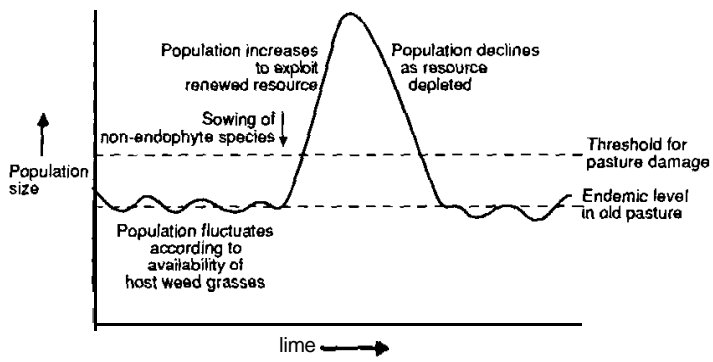

Figure 2 Changes in population size of Argentine stem weevil in relation to changes in the abundance of A. lolii-free tillers.

Argentine stem weevil response to endophyte infection involves several stages of the life cycle; viz reproductive development and dispersal, oviposition preferences, larval mortality. and depletion of food resources (Barker $\boldsymbol{e t}$ al. 1989). Although the number of A. Iolii-infected tillers affects all these processes, other factorsmay also influence the absolute population density and ultimately the degree of pasture damage. For example, the upper limit to the size of the population in an endophytefree pasture is influenced by the effect of weevil crowding on adult fecundity (Figure3). After adult emergence, a larger proportion of weevils developed flight musculature when confined on $A$. Iolii-infected ryegrasses compared with those on $A$. lolii-free grass, and athigherdensities (Figure 3). These studies indicate that adult stem weevils partition body resources to reproduction or dispersal in response to population density andthenumberof endophytefree tillers available. 

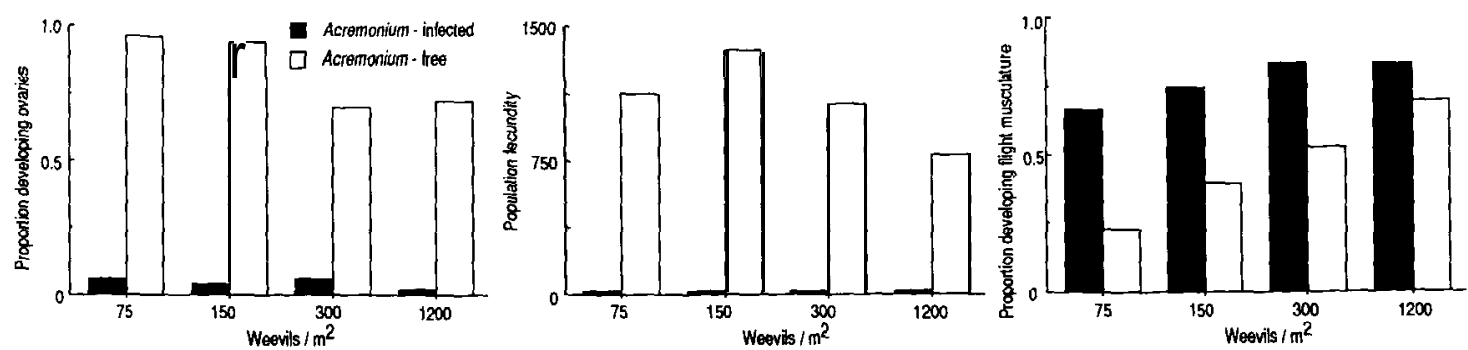

Figure 3 Response of Argentine stem weevil when confined at 4 densities in either $\boldsymbol{A}$, lolii-infected or A. Iolii-free swards.

\section{Selection of endophyte-free tolerant/ resistant ryegrasses}

The development of stem weevil tolerant/resistant perennial ryegrass cultivars is auseful alternative where ryegrass staggers is a persistent disorder. Previous attempts to identify sources of resistance to Argentine stem weevil inevitably identified $\boldsymbol{A}$. lolii-infected plants and seedlines (Kain et al. 1982). Easton \& Popay (1990) treated 250 diverse seedlines with fungicide toeliminate A. Lolii and screened these treated plants for resistance to adult stem weevil feeding. They identified a small number of plants with genetic resistance to stem weevil. In similar studies at Ruakura 703 perennial ryegrass seedlines from diverse origins were evaluated for tolerance/resistance to adult feeding and larval tiller mining in a screenhouse experiment. Only old seed, with non-viable endophyte was used. Ninety-six seedlines had higher vigour scores and a lower percentage of seedlings killed by Argentine stem weevil than $\boldsymbol{A}$. Iofii-infected Ellett which was used as a 'resistant' standard. As replicated single-row plots in the field, 12 of these seedlines had monthly vigour scores similar to that of $\boldsymbol{A}$. lolii-infected perennial ryegrass standards during summer and autumn (Table 3 ). All ryegrasses with high vigour scores were of New Zealand origin, confirming the results of Easton \& Popay (1990). Even seedlines from South America, where Argentine stem weevil is endemic, did not have any elevated level of resistance. The increased use of $A$. Z\&ii-infected seedlines since the 1980s with a high proportion of plants infected with $\boldsymbol{A}$, lolii will have forced Argentine stem weevil onto that small proportion free of $\boldsymbol{A}$. lolii, and thus increased selection pressure for genetic host plant resistance.

\section{Development of biological controls}

Our population studies indicate that pathogens and predators which reduce the adult reproductive capacity would complement existing density-dependent controls tomaintainstem weevil at low densities. During 1940s-
Table 3 Seasonal vigour scores (maximum 15) of selected lines of A.lolii-free ryegrasses for summer (Nov-Feb) and autumn (March$M$ ay) (Prestidge unpubl. data).

\begin{tabular}{ccr}
\hline & \multicolumn{2}{c}{ Vigour scores } \\
& Summer & Autumn \\
\hline Italian ryegrasses & & \\
Concord & 10.8 & 7.5 \\
Moata & 7.0 & 3.6 \\
Tama & 6.0 & 0.3 \\
A. /o/ii-infected perennial ryegrasses & & \\
Droughtmaster & 10.5 & \\
Ellett & 10.1 & 10.5 \\
Nui & 10.4 & 9.6 \\
Yatsyn 1 & 11.6 & 9.6 \\
& & 11.4 \\
Selected A. /o/ii-free perennial ryegrasses & \\
107B & 10.0 & 11.3 \\
41C & 10.3 & 10.8 \\
$43 \mathrm{C}$ & 10.9 & 11.4 \\
550 & 10.2 & 9.6 \\
$\mathbf{5 7 B}$ & 10.0 & 9.9 \\
a20 & 10.3 & 9.6 \\
$\mathbf{8 6 B}$ & 10.3 & 9.9 \\
940 & 10.1 & 9.8 \\
124B & 10.1 & 9.9 \\
1568 & 9.3 & 9.9 \\
$45 \mathrm{C}$ & 9.1 & 9.9 \\
$94 \mathrm{C}$ & 10.3 & 9.9
\end{tabular}

1960stheCommonwealthInstituteforBiologicalControl (CIBC) discovered a parasitoid of adult stem weevil, Microctonus hyperodae. The larvae of this tiny wasp liveas internalparasites. Aftertheparasite hasdeposited a single egg into the body cavity, the weevil is sterilised but stays alive and mobile. The parasite larva progresses through five instars after which it leaves the weevil to form a pupal cocoon on the soil surface. It is at this stage that the host weevil dies.

During 1988-90, members of MAF and DSIR made 3 visits to South America and found $M$. hyperodae to be more widely distributed and present in stem weevil at higher levels of infection than initially recognised by CIBC. By January 1990.7 lines of the parasitoid, from contrasting geographical areas in South America, had 
been established in quarantine at Lincoln, New Zealand (Goldson et al. 1990). Host range specificity tests were conducted on native weevils while in quarantine and an environmental impact assessment was submitted to the Ministry for the Environment. $\boldsymbol{M}$. hyperodae exhibited a high degree of host specificity to stem weevil and was approved for field release.

Release of breeding $M$. hyperodae populations at 6 sites throughout New Zealand commenced in winter 1991. Given the wide range of habitats from which it was collected in South America, there is a high probability that it will be able to establish in at least some areas of New Zealand. While the outcome of biological controls is uncertain, the high levels of parasitism noted in weevils in South America and in quarantine in $\mathrm{New}$ Zealand indicates, given successful establishment, that M. hyperodae should reduce the numbers of stem weevil in pastures. However, the effects may take several years to become apparent.

While considerable attention has been focused on the importation and release of $\boldsymbol{M}$. hyperodae, other studies have demonstrated the importance of pathogens occurring naturally in New Zealand. The fungus Beauveria bassiana, a ubiquitous pathogen of insects, occurs in New Zealand pastures on a number of insed hosts. This pathogen is particularly favoured by the humid conditions of the northern North Island where it causes Argentine stem weevil mortality in late autumn. These disease outbreaks occur too late in the autumn to prevent pasture damage by the larval stages of the weevil, but the epizootics are responsible for poor overwintering adult survival and contribute to small larval populations in spring (Barker et al. 1989).

Exploitation of $B$. bassiana as a biological insecticide is reliant on applying sufficient fungal spores to pasture in late spring to induce a disease outbreak before significant pasture damage by the larval stages. Current research has shown that Beauveria strains differ in pathogenicity to Argentine stem weevil, in ability to grow and sporulateon artificial media, and in temperature requirement. Our current efforts are in field evaluation of the most infective strains.

\section{Conclusions}

Argentine stem weevil is the most important economic insectpestofimprovedpasturesbutisunderconsiderable pressure from a range of sustainable, naturally occurring controls. The discovery of $A$. lolii-conferred ryegrass resistance, and the definition of the key processes and the major compounds responsible, have enabled the development of non-ryegrass staggers producing strains of endophyte. The discovery ofendophytefreeryegrasses that are tolerant/ resistant to Argentine stem weevil may provide a further means for overcoming ryegrass staggers in grazing animals and maintaining pasture productivity and persis tence. Controls based on parasitoids, pathogens and resistant plants have the potential to reduce stem weevil reproductive capacity and to be self-sustaining if compatible with the farmenvironment in which they are applied. A single agent is unlikely to effect control when acting alone. Indeed, reliance on a single control is not a sound policy, as a singlecomponent system may fail with time (Pottinger \& Wrenn 1989). Controls effected by plant resistance and natural enemies are usually additive, and often synergistic. A low cost, sustainable pest management system, compatible with farm management practices, is the aim for all the key pastoral pests in New Zealand.

\section{REFERENCES}

Ahmad, S.; Gorindarajan, S.; Funk, C.R.; JohnsonCicalese, J.M. 1985. Fatality of house crickets on perennial ryegrasses infected with a fungal endophyte. Entomologia experimentalis et applicata 39: 183-190.

Ahmad, S.; Johnson-Cicalese, J.M.; Dickson, W.K.; Funk, C.R. 1986. Endophyte-enhancedresistance in perennial ryegrass to the bluegrass billbug, Sphenophorus parvulus. Entomologiaexperimentals et applicata 41: 3-10.

Ball, O.J-P.; Prestidge, R.A. 1992. The effect of Acremonium lolii on adult black beetle (Heteronychus arator (f.)) feeding. Proceedings of the 45th NZ weed and pest control conference: in press.

Barker, G.M.; Baars, J.A. 1989. Effects of Argentine stem weevil on productivity of Waikato ( $\mathrm{New}$ Zealand) dairy pastures: impact assessment using a simple pasture growth model. Proceedings of the 5th Australasian conference on grassland invertebrate ecology: 304-313.

Barker, G.M.; Pottinger, R.P.; Addison, P.J. 1984a. Effect of Lolium endophyte fungus infections on survival of larval Argentine stem weevil. NZjournal of agricultural research 27: 278-281.

Barker, G.M.; Pottinger, R.P.; Addison, P.J.; Prestidge, R.A. 1984b. Effect of Lolium endophyte fungus infections on behaviour of adult Argentine stem weevil. NZ journal of agricultural research 27: 27 1277.

Barker, G.M.; Pottinger, R.P.; Addison, P.J. 1989. Population dynamics of the Argentine stem wevil (Listronotus bonariensis) in pastures of Waikato, New Zealand. Agriculture, Ecosystems and Environment 26: 79-। 15.

Barker, G.M.; Prestidge, R.A.; Pottinger, R.P. 1986. Strategies for Argentine stem weevil control: effects ofdrought andendophyte. ProceedingsNZGrassland Association 47: 107-114. 
Clay. K. 1990. Fungal endophytes of grasses. Annual review of ecology and systematics 21: 275-297.

Clay, K.; Hardy, T.N.; Hammond, A.M. 1985. Fungal endophytes of Cyperus and their effect on an insect herbivore. American journal of botany 72: 12841289.

Dymock, J.J.; Rowan, D.D.; M CGee,I.R. 1989. Effects of endophyte-produced mycotoxins on Argentine stem weevil and the cutworm Graphania mutans. Proceedings of the 5th Australasian conference on grassland invertebrate ecology: 35-43.

Easton,H.S.;Popay,A.J. 1990. Resistance in endophytefree ryegrass to Listronotus bonariensis. Proceedings of the international conference on Acremoniuml grass interactions: 134- 136.

Fletcher, L.R. 1986. Lolium endophyte and sheep performance on perennial ryegrass cultivars. Proceedings of the NZ Grassland Association 47: 99-105.

Fletcher, L.R.; Barrell, G.K. 1984. Reduced liveweight gains and serum prolactin levels in hoggets grazing ryegrasses containing Lolium endophyte. NZ veterinary journal 32: 139-140.

Fletcher, L.R.; Harvey, I.C. 1981. An association of Lolium endophyte with ryegrass staggers. NZ veterinary journal 29: 185-186.

Frost, W.E.; Quigley, P.E.; Cunningham, P.J. 1990. Research into the effect of Acremonium lolii on the feeding behaviour and nutrition of principal Australian pests of perennial ryegrass. Proceedings of the international symposium on Acremoniuml grass interactions: $144-146$.

Funk,C.R.; Halisky, P.M.; Johnson, M.C.; Siegel, M.R.; Stewart, A.V.; Ahmad, S.; Hurley, R.H.; Harvey, I.C. 1983. An endophytic fungus and resistance to sod webworms: Association in Lolium perenne $\mathrm{L}$. Bio/Technology 1: 189-191.

Gallagher, R.T.; Prestidge, R.A. 1990. Structure activity studies on indolediterpenes, including lolitrems and related indoles and tremorgens. Proceedings of the international symposium on Acremoniumlgrass interactions: $80-83$.

Goldson, S.L.;McN eill,M .R.; Stufkens, M.W.; Proffitt, J.R.; Pottinger, R.P.; Farrell, J.A. 1990. Importation and quarantine of Microctonus hyperodae. a South American parasitoid of Argentine stem weevil. Proceedings of the 43rd NZ weed and pest control conference: $334-338$.

Hardy, T.N.; Clay, K.; Hammond, A.M. 1985. Fall armyworm (Lepidoptera: Noctuidae): A laboratory bioassay and larval preference study for the fungal endophyte of perennial ryegrass. Joumal of economic entomology 78: 51 I-515.

Johnson, MC.; Dahlman, D.L.; Siegel, M.R.; Bush, L.P.; Latch, G.C.M.; Potter, D.A.; Vamey, D.R.
1985. Insect feeding deterrents in endophyte-infected tall fescue. Applied environmental microbiology 49: 568-571.

Kain, W.M.; Slay, M.W.; Wyeth, T.K. 1982. Identification, occurrence, and development of Argentine stem weevil (Hyperodes bonariensis Kuschel) resistance in perennial ryegrass (Lolium perenne L.). Proceedings of the 3rd Australasian conference on grassland invertebrate ecology: 265 271.

Kirfman, G.W.; Brandenburg, R.L.; Garner, G.B. 1986. Relationship between insect abundance and endophyte infestationlevel in tall fescue inMissouri. Journal of the Kansas Entomological Society 59: 552-554.

Latch, G.C.M. 1989. Plant improvements using endophyte fungus. Proceedings of the 16th international grasslands congress: $345-346$.

Latch,G.C.M. 1991. Biotic stress tolerance of endophyteinfected grasses. In Quisenberry, S.; Joost, R. (eds). Grass/Acremonium Interactions, Elsevier Press, Amsterdam: In press.

Latch, G.C.M.; Christensen, M.J.; Gaynor, D.L. 1985. Aphid detection of endophyte infection in tall fescue. NZ journal of agricultural research 28 : 129-132.

Latch, G.C.M.; Christensen, M.J.; Samuels, G.J. 1984. Five endophytes of Lolium and Festuca in N ew Zealand. Mycotaxon 20: 535-550.

Latch, G.C.M.; Potter, L.R.; Tyler, B.F. 1987.Incidence of endophytes in seeds from collections of Lolium and Festuca spp. Annals of applied biology 111: 59. 64.

Marshall, G.A.K. 1937. New Curculionidae collected from New Zealand. Transactions of the N.Z. Institute 67: 316-340.

Mathias, J.K.; Ratcliffe, R.H.; Hellman, J.L. 1990. Association of an endophytic fungus in perennial ryegrass and resistance to the hairy chinch bug (Hemiptera: Lygaeidae). Journal of economic entomology 83: 1640-1646.

Mortimer, P.H. 1983. Ryegrass staggers: Clinical, pathological and aeteological aspects. Proceedings of the NZ Grassland Association 44: 230-233.

Pearson, W.D. 1989. The pasture mealybug, Balanococcus poae (Maskell) in Canterbury: a preliminary report. Proceedings of the 5th Australasian conference on grassland invertebrate ecology: 297-303.

Peterson, A.J.; Bass, J.R.;Byford,M.J. 1978. Decreased plasma testosterone concentrations in rams affected by ryegrass staggers. Research inveterinary science 25: 266-268.

Peterson, A.J.; Bass, J.R.; Byford,M.J. 1984. Decreased plasma testosterone concentrations and weight gain 
in young bulls affected by ryegrass staggers. NZ veterinary journal 32: 36-37.

Popay, A.J.; Prestidge, R.A.; Rowan, D.D.; Dymock, J.J. 1990. The role of Acremonium lolii mycotoxins in insect resistance of perennial ryegrass (Lolium perenne). Proceedings of the international conference on Acremonium/grass interactions: 4449.

Pottinger. R.P. Wrenn, R.N. 1989. Factors affecting trends in pasture pest research and control in New Zealand. Proceedings of the 5th Australasian grassland invertebrate ecology conference: 28 1288.

Prestidge, R.A. 1991. Causes and control of perennial ryegrass staggers in New Zealand. In Quisenberry, S.; Joost, R. (eds). Grass/Acremonium Interactions, Elsevier Press, Amsterdam: In press.

Prestidge, R.A.; Barker, G.M.; Pottinger. R.P. 1991. The economic cost of A rgentine stem weevil in pastures in New Zealand. Proceedings of the 44th NZ weed and pest control conference: 165170.

Prestidge. R.A.; Gallagher, R.T. 1988. Endophyte fungus confers resistance to ryegrass: Argentine stem weevil larval studies. Ecologicalentomology 13: 429-435.

Prestidge, R.A.; Pottinger. R.P.; Barker, G.M. 1982. An association of Lolium endophyte with ryegrass resistance to Argentine stem weevil. Proceedingsof the 35 th NZ weed and pest control conference: 119 . 122.

Prestidge, R.A.; Van der Zijpp, S.; Badan, D. 1984. Effects of stem weevil in pasture in the volcanic plateau. NZ journal of experimental agriculture 12: 323-331.

Prestidge, R.A.; di Menna, M.E.; Van der Zijpp, S.; Badan, D. 1985. Ryegrass content, Acremonium endophyte and Argentine stem weevil in pastures in the volcanic plateau. Proceedings of the 38th NZ weed and pest control conference: 4 l-44.

Rowan, D.D.; Gaynor, D.L. 1986. Journal of chemical ecology 12: 647-658.

Rowan, D.D.; Shaw, G.S. 1987. Detection of ergopeptine alkaloids in endophyteinfected perennial ryegrass by tandem mass spectroscopy. NZ veterinaryjournal 35: 197-198.

Vamey, D.R.; Prestidge, R.A.; Jones, D.D.; Vamey, L.A.; Zavos, P.M.; Siegel, M.R. 1989. Effect of endophyteinfected perennial ryegrass seed diets on growth and reproduction in mice. NZ journal of agricultural research 32: 547-554.

Wilson, A.D.; Clement, S.L.; Kaiser, W.J. 1991. Survey and detection of endophytic fungi in Lolium germplasm by direct staining and aphid assays. Plant disease 75: 169-173. 